

\section{WELCOMING REMARKS}

It is with great pleasure as well as honor to welcome you all to the 4th International Seminar on Tourism (ISOT) 2020 hosted by Department of Tourism, Faculty of Social Sciences Education, Universitas Pendidikan Indonesia (UPI), Indonesia. Featuring the theme of "Promoting Creative Research: Current Issues in Tourism Research", the seminar aims to bring together scientists, academics, researchers, and practitioners to share their knowledge, research results, and experiences despite the global pandemic of COVID-19. The seminar was initially set to take place at UPI on 4-5 November 2020; however, due to the uncertainties of the pandemic, the organizing committee has come to an agreement to hold it virtually on 4 November 2020. The occurrence is exactly in line with the theme as the organizing committee, along with the other co-hosting universities, have to cope with the situation through a creative solution. This year, we invited three speakers: Professor Bob McKercher from The Hongkong Polytechnic University; Professor Iis Tussyaidah from University of Surrey, United Kingdom; and Dr. Dewi Turgarini, MM.Par. from Universitas Pendidikan Indonesia, Indonesia to give a talk in relation to the theme. Following the plenary session by the three speakers, we also have a parallel session in which the speakers have to attend their assigned room(s) and present their paper(s).

In addition to fruitful discussions through both plenary and parallel sessions, we take into account the importance of paper dissemination through international publication. This year, we managed to have a publication collaboration with Routledge and CRC Press, a member of Taylor \& Francis group, one of the "Ivy League" squad within the publication context. There are 112 papers to be published within the platform discussing a variety of scope including Community-Based Tourism, Destination Management, Tourism and Education, Tourism Gastronomy, Hospitality Management, Safety and Crisis Management, and Tourism Marketing. I do hope the publication benefits as many people as possible, particularly in such a strange and difficult time.

The conference is made possible because of collaborative works of several parties. First of all, I would like to express my deepest gratitude to the Rector of UPI. Prof. Dr. M. Solehudin, M.Pd., M.A.and Vice Rector for Research, International Affairs, Business, and Partnership, Prof. Dr. Adang Suherman, M.A. for their endless support regarding the university's publication productivity. Secondly, I would like to thank all the leaders at the Faculty of Social Sciences Education, UPI, and Department of Tourism, UPI for facilitating the seminar. Last but not least, I would like to deliver many thanks to all the co-hosting institutions: STIEPAR YAPARI, Universitas Negeri Jakarta, Universitas Kristen Petra, and Sekolah Tinggi Pariwisata Trisakti and all the committee members of The 4th ISOT 2020 for all the hard work. Looking forward to seeing you all at the 4th ISOT 2020.

Dr. Ahmad Hudaiby Galih Kusumah, M.M.

Chairman ISOT 


\section{LIST OF COMMITTEES}

\section{Advisory Board}

Dr. Eunice Tan (Murdoch University Singapore, Singapore)

Dr. Christina Lam (SIT)

Dr. Walanchalee Wattana (Mahidol University)

Dr. Eka Putra (Sol International Hospitality Management (SIHOM), Sol International School

(SIS), Woosong University)

Hera Oktadiana Ph.D. (James Cook University, Australia)

Yong-Jae Choi, Ph.D. (Hankuk University of Foreign Studies)

Prof. Neil Carr (University of Otago, New Zealand)

Dr. Craig Lee (University of Otago, New Zealand)

Dr. Manisa Piuchan (Chiang Mai University)

Dr. Pipatpong Fakfare (School of Humanities and Tourism Management, Bangkok University, Thailand)

Dr. Jiwon Seo (Ewha Woman's University, Seoul, South Korea)

Dr. Luk Kiano (Community College of City University Hong Kong, Hongkong)

Dr. Ryan Smith (San Francisco State University, USA)

Prof. Dr. Elly Malihah M.Si. (Universitas Pendidikan Indonesia, Indonesia)

Prof. Dr. Darsiharjo M.S. (Universitas Pendidikan Indonesia, Indonesia)

Caria Ningsih, Ph.D. (Universitas Pendidikan Indonesia, Indonesia)

Dr. Erry Sukriah (Universitas Pendidikan Indonesia, Indonesia)

Usep Suhud Ph.D. (Universitas Negeri Jakarta, Indonesia)

Dr. Myrza Rahmanita (STP Trisakti, Indonesia)

Dr. Liga Suryadana (STP Enhaii, Indonesia)

Dr. Any Ariani Noor S.Pd., M.Sc. (Polban, Indonesia)

Dr. Marceilla Hidayat B.A.Honns., M.M. (Polban, Indonesia) 


\section{Steering Committee}

Prof. Dr. M. Solehuddin, M.Pd., M.A.

Prof. Dr. H. Adang Suherman, M.A.

Dr. Agus Mulyana, M. Hum.

Dr. H. Mamat Ruhimat, M.Pd.

Dr. H. Aceng Kosasih, M.Ag.

Dr. Hj. Siti Nurbayani K., M.Si.

Prof. Dr. Elly Malihah, M.Si.

Prof. Dr. Darsiharjo. M.S.

Dr. Erry Sukriah, M.SE.

Caria Ningsih, Ph.D.

Oce Ridwanudin, M.M.

\section{Organizing Committee \\ Chairman:}

Dr. Ahmad Hudaiby Galih Kusumah, M.M.

\section{Co-host:}

Khrisnamurti (Universitas Negeri Jakarta, Indonesia)

Rina Suprina (Trisakti School of Tourism, Indonesia)

Sienny Thio (Petra Christian University, Indonesia)

Nova Riana (Sekolah Tinggi Ilmu Ekonomi Pariwisata Yapari, Indonesia)

\section{Secretary:}

Dr. Dewi Turgarini M.M.Par.

\section{Treasurer:}

Agus Sudono, M.M.

Yeni Yuniawati M.M.

\section{Secretarial Division:}

Ghoitsa Rohmah Nurazizah, S.Par., M.Si.

Endah Fitriyani, S.Par., MM.Par.

Wida Budiarti, S.Pd.

Galih Nurul Rahmadiana, S.Par.

\section{Website:}

Reiza Miftah Wirakusuma, S.ST.Par., M.Sc.

Riko Arrasyid, M.Pd.

\section{Members:}

Rijal Khaerani, S.Si., M.Stat.

Woro Priatini, S.Pd., M.Si.

Cep Ubad Abdullah, M.Pd.

H.P. Diyah Setiyorini, M.M.

Ilma Indriasri Pratiwi, S.E., M.P.Par.

Nuzep Almigo, Ph.D.

Nurimani, S.Sos., M.M.

Isti Septiani, S.Pd.

Arni Gantini, A.Md. 


\section{TABLE OF CONTENTS}

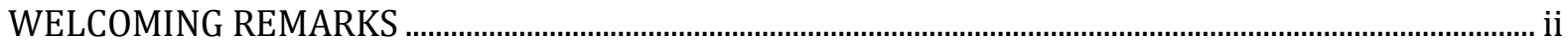

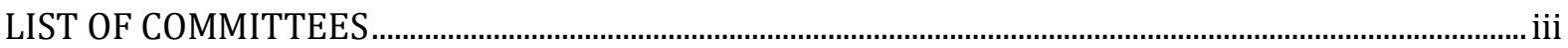

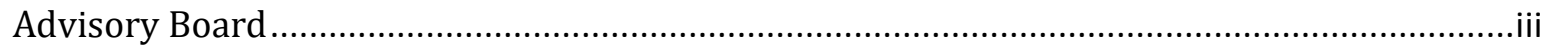

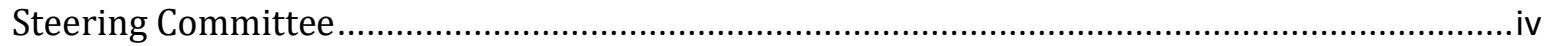

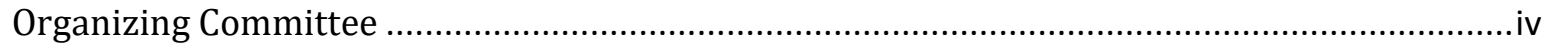

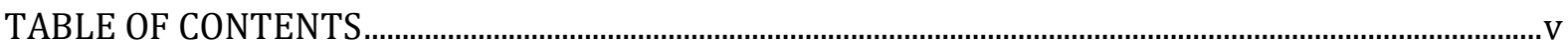

PROGRAM SCHEDULE ………………..............................................................................................

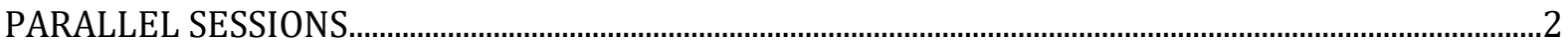

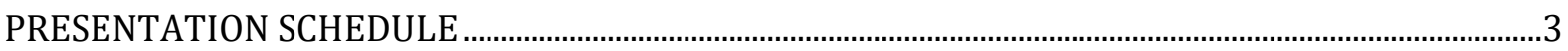

Breakout Room 1: Community Based Tourism \& Destination Management............................... 3

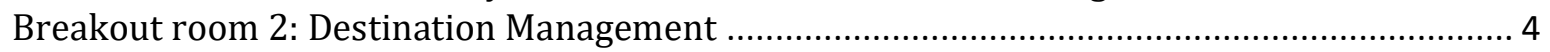

Breakout room 3: Hospitality Management \& Destination Management ................................... 5

Breakout room 4: Tourism and Education \& Gastronomy Tourism ....................................... 6

Breakout room 5: Security and Crisis Management in Tourism ……...................................... 7

Breakout room 6: Tourism Marketing \& Gastronomy Tourism .............................................. 8

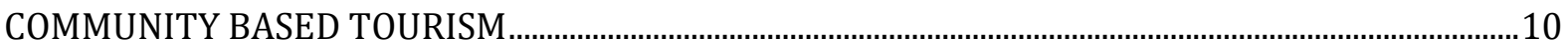

Border community perception of their local tourist attraction................................................ 10

Language style and local wisdom in the travel documentary Pesona Indonesia: Tondokku

Kondosapata on TVRI as a medium for tourism promotion ................................................... 11

Community education in developing edutourism values in Geopark Ciletuh .......................... 12

Building the character of community tourism village in the preservation of Culture Ngalaksa

Development strategies for parenting tourism villages based on digital literacy $\ldots$

Citizenship education in community development in indonesia: reflection of a community

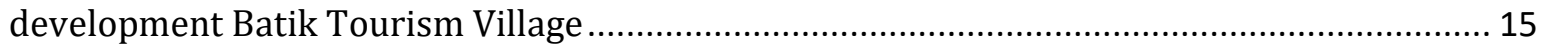

Poverty alleviation in tourism destination: a new village-owned enterprise in the Southern

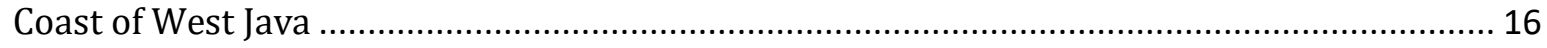

Readiness and participation of local community for river-based tourism development in

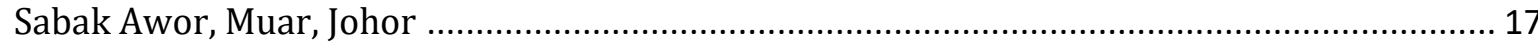

Local community's cultural attitudes towards support for tourism development and

conservation in archaeological heritage of the Lenggong Valley ............................................ 18

Rural tourism in Jakarta (Ecotourism in pasanggrahan riverbank) ........................................ 19

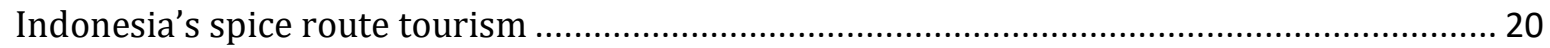

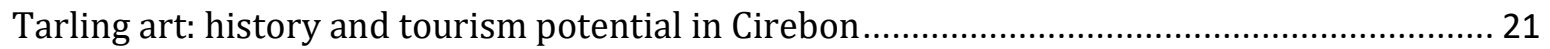

Tourism and spiritual journey from students' perspective and motivation.............................. 22

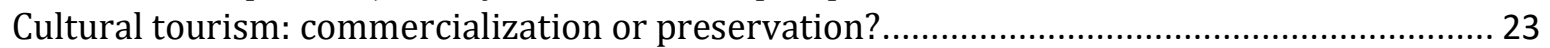

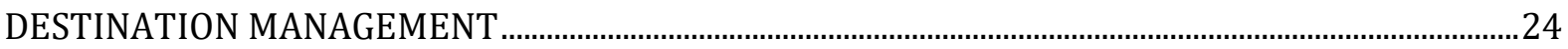

The crucial attributes for culinary tourism destination based on tourists' perception ............ 24

Border tourism in Indonesia's outer islands: the case of Sebatik Island ................................. 25

Visitor satisfaction: the mediating role of crowding perception on environmental

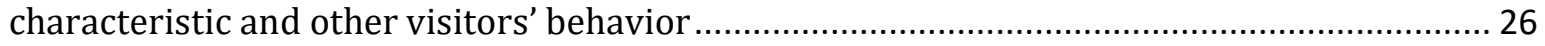

Culinary tourism planning and development: a case in Gebang Mekar Cirebon ...................... 27

Tour guides' multilingualism in the city of Bandung, Indonesia: what does the policy say? .... 28

Tourist preferences of activities in the tourist village .......................................................... 29

The influence of Bandung city image as a fashion city on tourist satisfaction ........................... 30

The influence of destination image on revisit intention in Olele Marine Park .......................... 31 
Topeng Pedalangan as a tourist attraction in Gunungkidul Regency Special Region of Yogyakarta 32

Millennial volunteer tourist motivation in West Java Province, Indonesia ............................... 33

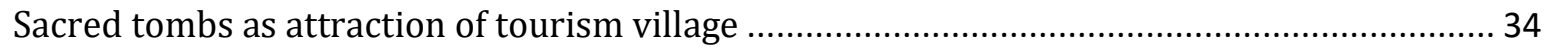

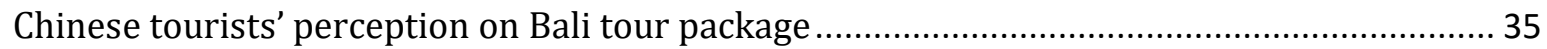

Transformational leadership, perceived organizational support, and workplace spirituality on employee engagement of restaurant employees in Surabaya .................................................. 36

Destination personality of Labuan Bajo, Indonesia: local and foreign tourists' perspectives.. 37 Development of tourist visitor management system in Tajur Kahuripan traditional tourism village......

Projected destination image on instagram amidst a pandemic: a visual content analysis of

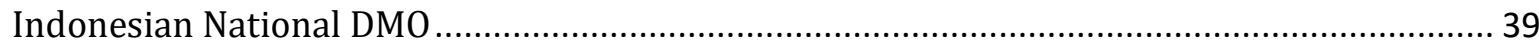

Analysing the factors affecting the purchasing decision over Malaysian Batik products ......... 40 Indonesia mythology as touristic attractiveness: the story of the queen of the Southern Sea of Java Island.

The role of psychographic factors in predicting volunteer tourists' stage of readiness: a case of

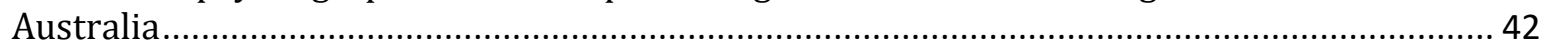

Turkish destination image and attitude toward Turkish television drama................................ 43

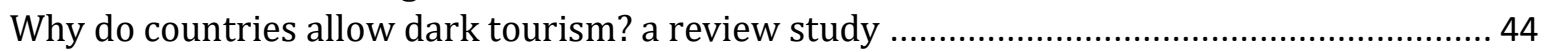

Understanding the motivations and preference on ecotourism development: the case of

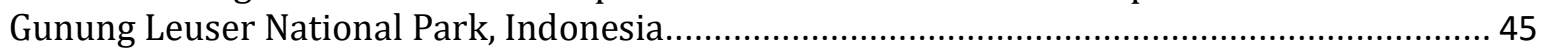

Sequential exploratory mixed methods and scale development: investigating transformational

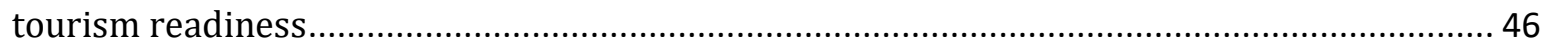

Economic benefits of selected resorts in Dasmariñas City, Cavite: basis for a proposed

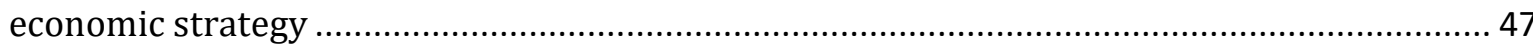

Tourism development and the well-being of local people: findings from Lembang, West Java,

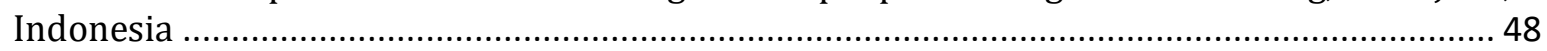

The effect of individual and destination accessibility on willingness to visit: nature-based

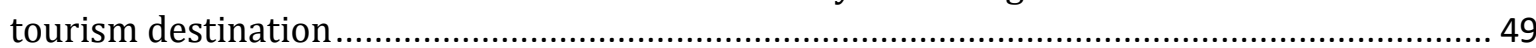

Push and pull factors in visiting a remote nature-based destination....................................... 50

Can marine debris pollution cause the loss of tourism revenue in Indonesia? an empirical

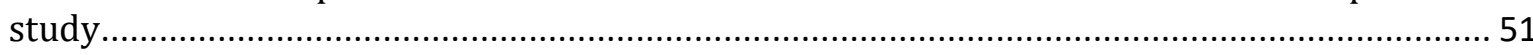

How risky is liveaboard diving in Indonesia? an empirical investigation on the divers

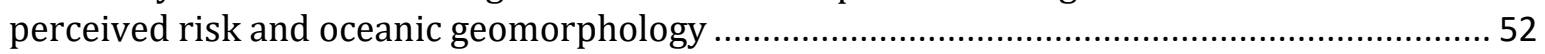

Challenges in sustainable design practices through the lenses of local event organizers ........ 53

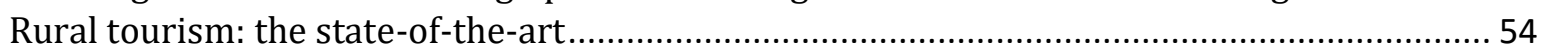

Hand sign method in playing angklung as tourists' involvement on creative tourism: a case

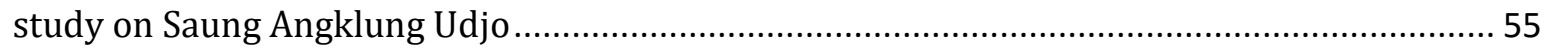

Potential of domestic tourist loyalty in Indonesia: a spatial analysis ..................................... 56

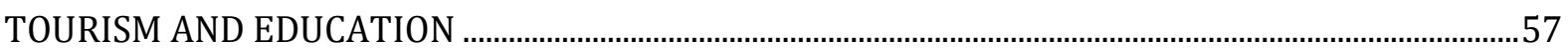

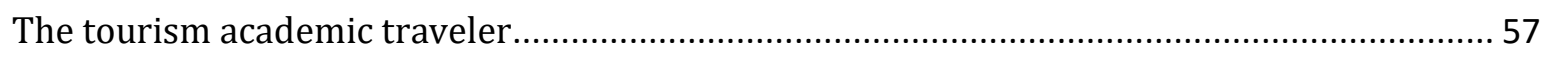

Competency development problems in tourism and hospitality students' internship in

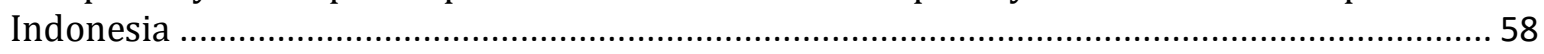

Integrative teaching materials for Indonesian speakers of other languages based on

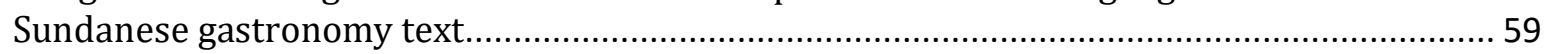

CIPP model: curriculum evaluation of the Indonesian gastronomy courses............................60

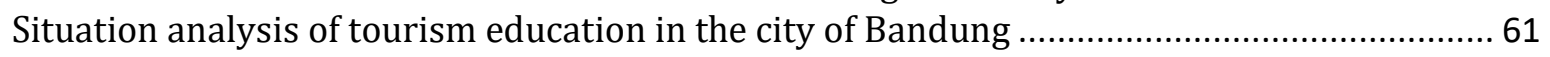

Analysis of online learning in pandemic COVID-19 in tourism education ................................. 62

Development of friendly character and working characters for tourism guide practices of

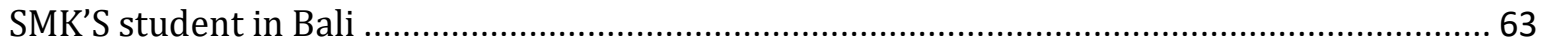

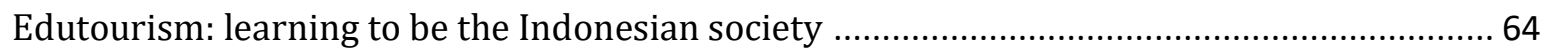


Interculture language learning: literacy level determines the development of tourist numbers in Indonesia?.

CATC implementation to strengthen the industrial based tourism competency of vocational school

An exploratory study on Singapore Polytechnic Hospitality and Tourism students' perception towards the use of virtual learning environments (e-learning).....

The challenge in disruptive times in tourism education: towards a redesigned curriculum for new normal from conventional to creative tourism .68 The suitability of TOEFL-ITP as a tourism industry employment requirement for Indonesian university graduates

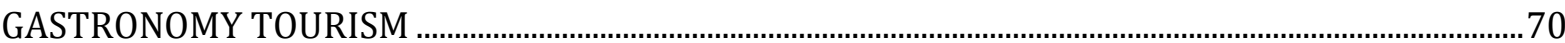

Canna fettucine: commodifying culinary Italian Indonesian.................................................. 70

The Salapan Cinyusu (nona helix) as a "creativepreneurship" support model for gastronomy tourism in Bandung city....

The effect of gastronomic festival attributes on behavioral intention at Wisata Kuliner Tjeplak

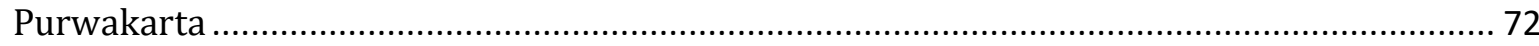

Culinary experience toward behavioral intention (survey of consumer fusion food on street

food in Bandung city).....

Implications of food delivery services for recognition of traditional foods by millennials in

Bandung

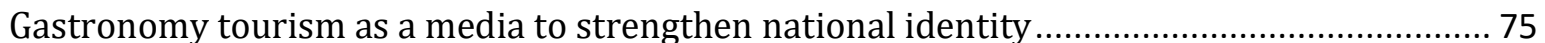

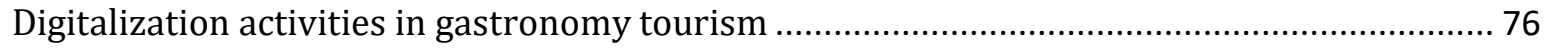

Tape Kareueut Teh Bohay: students' gastronomic tourism capital Universitas Pendidikan

Indonesia

Gastronomy tourism development model on a tourist village .....

Exploring the expectation of youth purchasing intention for street food as a gastronomy tourism in Bangsaen, Thailand.

iDabao during COVID-19: online-to-offline (o2o) food delivery service and the digitalization of hawker (street) food during a crisis.

HOSPITALITY MANAGEMENT.

Re-examining sensory experience on highland nature-based resort rooms............................ 81

Consumer's complaint behavior between Indonesian and Non-Indonesian in the hotel......... 82

Exploring factors influencing homestay operators to participate in the homestay program .. 83

Analysing the tourist's e-satisfaction of hotel booking website towards online purchase

intention in Malaysia....

Sharia-compliant hotel literacy: Profiling the potential sharia-compliant hotel guest............. 85

Environment, food, or employee: identifying factors in authentic dining experience

influencing customer satisfaction

The effect of perceived authenticity on revisit intention in Sundanese Restaurant ................ 87

The impact of dining experience towards revisit intention at Mujigae Resto, Bandung ..........88

Legal and business sustainability of social enterprises restaurants ......................................... 89

Restaurant selection of Thai Free Individual Traveler (FIT) by using Conjoint Analysis

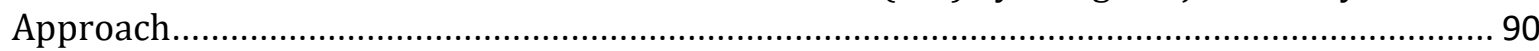

SECURITY AND CRISIS MANAGEMENT IN TOURISM.........................................................................91

COVID-19 and Indonesian super-priority tourism destinations ............................................ 91

The influence of perceived risk and perceived value toward tourist satisfaction.....................92

Hospitality industry crisis: how to survive and recovery in the pandemic of COVID-19 ........ 93

From fantasy to reality: Attracting the premium tourists after COVID-19 .............................. 94

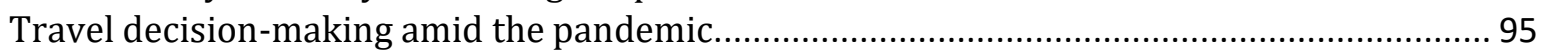

Tourism industry standard operating procedure adaptation preparing COVID-19 new normal

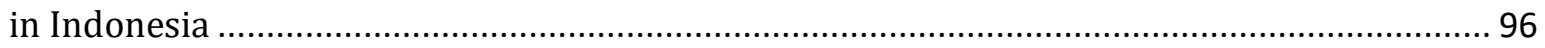




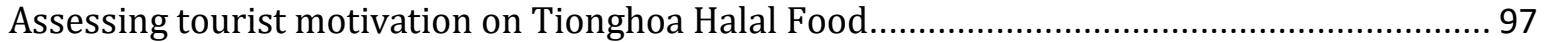

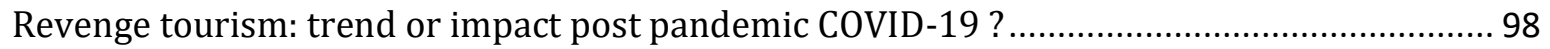

Spiritual tourism: study of the experience of fasting on Ramadan during the COVID-19

pandemic in Indonesia

The new era of tourism: draw up tourism industry after pandemic.................................... 100

Tourism and tourism crisis management in the COVID-19 pandemic time ........................... 101

Differences in trust and risk-taking propensity for travelers from Indonesia ........................ 102

The impact of travel constraints on travel intention .............................................................. 103

The effect of COVID-19 outbreak to the destination choice and the intention to visit the

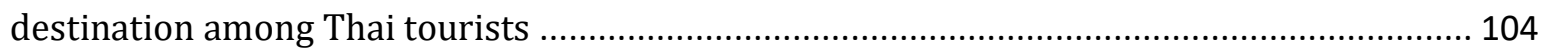

The impacts of COVID-19 at Karangsong Mangrove Centre .................................................. 105

Impacts of COVID-19 on national security in Indonesia and the alternative of national policy

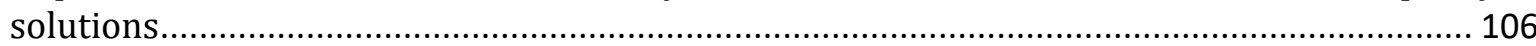

Covid-19, Technology and Tourism: the future of virtual tour? ........................................... 107

Virtual tour as one of education tourism solutions in COVID-19 pandemic........................... 108

Estimation of short-term economic effect in Geopark Ciletuh-Palabuhanratu tourism due to

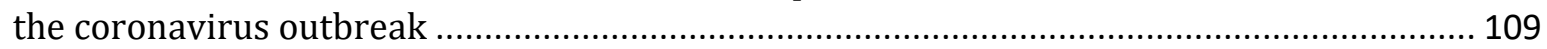

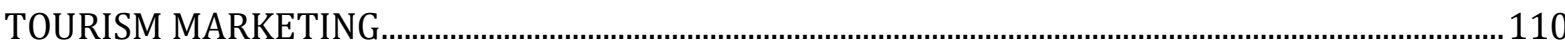

The effect of tourist satisfaction in the relationship between experiential marketing and

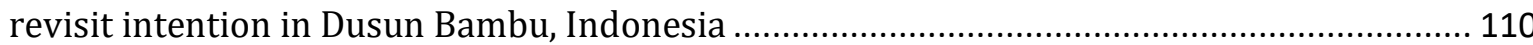
Virtual public sphere: The overview of instagram users in responding to the instagram posts

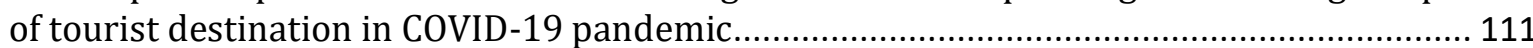

Visual Ethnography: Tourists' Perception of Bandung's Destination Image ........................... 112

What makes visitors come again to food festivals? An analysis of a direct influence of culinary

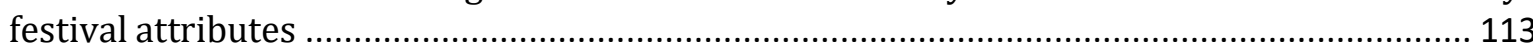

Women's mountaineering tourism on Instagram: the paradox between gender equality,

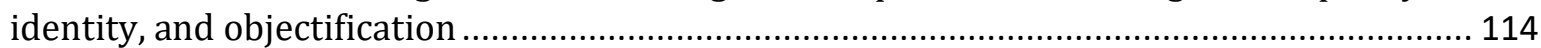

Image of 10 prioritized tourism destinations and its influence on eWOM among tourism

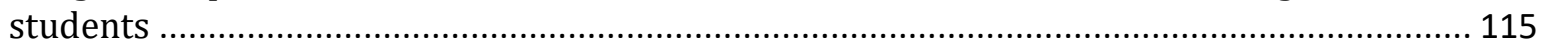

Nation brand culture tourism to improve the Nation image .............................................. 116

The role of social media in Generation Z travel decision-making process ............................ 117

The influence of halal tourism destination attributes on tourist satisfaction in Bandung ..... 118 mGuiding (Mobile Guiding) - Using a Mobile GIS app for Guiding Geopark Ciletuh

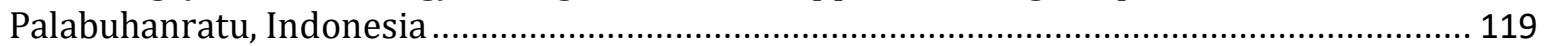

Virtual tour: Tourism opportunities in the new normal era................................................. 120

The Effect of Internet Marketing and Electronic Word of Mouth of Sundanese Gastronomy

Tourism on Tourist Visit Motivation to Bandung. 


\section{PROGRAM SCHEDULE}

The $4^{\text {th }}$ INTERNATIONAL SEMINAR ON TOURISM (ISOT) UNIVERSITAS PENDIDIKAN INDONESIA, NOVEMBER 4, 2020

\begin{tabular}{|c|c|c|c|}
\hline NO & TIME & ACTIVITY & VENUE \\
\hline 1 & $\begin{array}{c}08.00-09.00 \\
\text { WIB } \\
\text { (Western Time } \\
\text { of Indonesia) }\end{array}$ & Registration & Main Meeting room \\
\hline 2 & $09.00-09.30$ & $\begin{array}{l}\text { Opening Ceremony } \\
\text { The National Anthem - Indonesia Raya } \\
\text { Welcoming Speech: } \\
\text { 1. Dr. A.H. Galih Kusumah, M.M. } \\
\text { (Chairman ISOT) } \\
\text { 2. Dr. Agus Mulyana, M.Hum. } \\
\text { (Dean Faculty of Social Sciences Eduation) } \\
\text { 3. Prof. Dr. M. Solehuddin, M.Pd., M.A. } \\
\text { (Rector of Universitas Pendidikan Indonesia) } \\
\text { Master of Ceremony: } \\
\text { Cep Ubad Abdullah, M.Pd. } \\
\text { (mahasiswa) }\end{array}$ & $\begin{array}{c}\text { Main Meeting room \& } \\
\text { Numan Sumantri Building } \\
\text { room } 103\end{array}$ \\
\hline 4 & $09.30-11.00$ & $\begin{array}{l}\qquad \text { Plenary Session } \\
\text { Keynote Speakers: } \\
\text { Prof. Bob McKercher } \\
\text { The Hong Kong Polytechnic University, } \\
\text { Hong Kong } \\
\text { Prof. Iis Tussyadiah } \\
\text { University of Surrey, United Kingdom } \\
\text { Dr. Dewi Turgarini, M.M.Par. } \\
\text { Universitas Pendidikan Indonesia, Indonesia } \\
\text { Chair Session: } \\
\text { HP Diyah Setiyorini, M.M. }\end{array}$ & Main Meeting room \\
\hline 5 & $11.00-11.45$ & Question and answer & Main Meeting room \\
\hline 7 & $11.45-12.00$ & ISOT announcements & Main Meeting room \\
\hline 8 & $12.00-13.00$ & Break & \\
\hline 9 & $13.00-15.00$ & Parallel session 1 & Breakout room \\
\hline 10 & $15.00-15.30$ & Break & \\
\hline 11 & $15.30-17.00$ & Parallel session 2 & Breakout room \\
\hline 12 & $17.00-17.30$ & \begin{tabular}{l}
\multicolumn{2}{c}{ Closing ceremony } \\
Chanting Prayer \\
ISOT announcements
\end{tabular} & Main Meeting room \\
\hline
\end{tabular}




\section{PARALLEL SESSIONS}

\begin{tabular}{|c|c|}
\hline BREAKOUT RO0M & MODERATOR: \\
\hline $\begin{array}{c}\text { Breakout room 1: } \\
\text { Community Based Tourism \& Destination Management }\end{array}$ & Agus Sudono, M.M. \\
\hline $\begin{array}{c}\text { Breakout room 2: } \\
\text { Destination Management }\end{array}$ & Nuzep Almigo, Ph.D. \\
\hline Breakout room 3: & Reiza Miftah Wirakusuma, \\
S.ST.Par., M.Sc.
\end{tabular}




\section{PRESENTATION SCHEDULE}

\section{Breakout Room 1: Community Based Tourism \& Destination Management}

\begin{tabular}{|c|c|c|c|c|}
\hline No & Time & Code & Title & Author(s) \\
\hline 1 & $13: 00-13: 10$ & ISOT001 & $\begin{array}{l}\text { Border community perception of their } \\
\text { local tourist attraction }\end{array}$ & $\begin{array}{l}\text { A. Khosihan, A.R. Pratama, } \\
\text { P. Hindayani }\end{array}$ \\
\hline 2 & $13: 10-13: 20$ & ISOT002 & $\begin{array}{l}\text { Language style and local wisdom in The } \\
\text { Travel Documentary Pesona Indonesia: } \\
\text { Tondokku Kondosapata on TVRI as a } \\
\text { medium for tourism promotion }\end{array}$ & $\begin{array}{l}\text { S. Hamidah, N.N. Afidah, I. } \\
\text { Kurniawaty, H.T. Abdillah, } \\
\text { R.H. Nugraha }\end{array}$ \\
\hline 3 & $13: 20-13: 30$ & ISOT003 & $\begin{array}{l}\text { Community education in developing } \\
\text { edutourism values in Geopark Ciletuh }\end{array}$ & $\begin{array}{l}\text { D.S. Logayah, M. Ruhimat, } \\
\text { R. Arrasyid }\end{array}$ \\
\hline 4 & $13: 30-13: 40$ & ISOT004 & $\begin{array}{l}\text { Building the character of community } \\
\text { tourism village in the preservation of } \\
\text { Culture Ngalaksa }\end{array}$ & $\begin{array}{l}\text { D.M. Nugraha, Supriyono, } \\
\text { A. Gumelar }\end{array}$ \\
\hline 5 & $13: 40-13: 50$ & ISOT005 & $\begin{array}{l}\text { Development strategies for parenting } \\
\text { tourism villages based on digital } \\
\text { literacy }\end{array}$ & $\begin{array}{l}\text { N.N. Afidah, D.M. Nugraha, } \\
\text { A. Gumelar, P. Hyangsewu, } \\
\text { Y.A. Tantowi }\end{array}$ \\
\hline 6 & $13: 50-14: 00$ & ISOT006 & $\begin{array}{l}\text { Citizenship education in community } \\
\text { development in Indonesia: reflection of } \\
\text { a community development Batik } \\
\text { Tourism Village }\end{array}$ & $\begin{array}{l}\text { Katiah, A. Dahliyana, } \\
\text { Supriyono , V.A. Hadian }\end{array}$ \\
\hline 7 & $14: 00-14: 10$ & ISOT007 & $\begin{array}{l}\text { Poverty alleviation in tourism } \\
\text { destination: A new village-owned } \\
\text { enterprise in the southern coast of West } \\
\text { Java }\end{array}$ & $\begin{array}{l}\text { A.W. Handaru, U. Suhud, S. } \\
\text { Mukhtar }\end{array}$ \\
\hline 8 & $14: 10-14: 20$ & ISOT008 & $\begin{array}{l}\text { Readiness and participation of local } \\
\text { community for river-based tourism } \\
\text { development in Sabak Awor, Muar, } \\
\text { Johor }\end{array}$ & $\begin{array}{l}\text { S.N.A. Zuhairi, N.H.A. } \\
\text { Rahman, S.A. Abas, S.S.M } \\
\text { Sawari, S.A.A. Latif, R.M. } \\
\text { Wirakusuma }\end{array}$ \\
\hline 9 & $14: 20-14: 30$ & ISOT009 & $\begin{array}{l}\text { Local community's cultural attitudes } \\
\text { towards support for tourism } \\
\text { development and conservation in } \\
\text { archaeological heritage of the Lenggong } \\
\text { Valley }\end{array}$ & $\begin{array}{l}\text { A. Siti Aisah, M.A. Nur } \\
\text { Afiqah, A.R. Nur Hidayah, } \\
\text { M.S. Siti Salwa, G.R. } \\
\text { Nurazizah }\end{array}$ \\
\hline 10 & $14: 30-14: 40$ & ISOT010 & $\begin{array}{l}\text { Rural tourism in Jakarta (Ecotourism in } \\
\text { Pasanggrahan Riverbank) }\end{array}$ & $\begin{array}{l}\text { E. Maryani, Amin , N. } \\
\text { Supriatna, M. Ruhimat }\end{array}$ \\
\hline 11 & $14: 40-14: 50$ & ISOT011 & Indonesia's spice route tourism & $\begin{array}{l}\text { N. Fathiraini, D.P. Novalita, } \\
\text { Labibatussolihah , E. } \\
\text { Fitriyani }\end{array}$ \\
\hline 12 & $14: 50-15: 00$ & ISOT012 & $\begin{array}{l}\text { Tarling art: history and tourism } \\
\text { potential in Cirebon }\end{array}$ & A. Mulyana, S. Sartika \\
\hline & $15: 00-15: 30$ & \multicolumn{3}{|c|}{ BREAK } \\
\hline 13 & $15: 30-15: 40$ & ISOT013 & $\begin{array}{l}\text { Tourism and spiritual journey from } \\
\text { students' perspective and motivation }\end{array}$ & $\begin{array}{l}\text { S.P. Pandia, M.D. Kembara, } \\
\text { A. Gumelar, H.T. Abdullah }\end{array}$ \\
\hline 14 & $15: 40-15: 50$ & ISOT014 & $\begin{array}{l}\text { Cultural tourism: Commercialization or } \\
\text { preservation? }\end{array}$ & $\begin{array}{l}\text { E. Malihah, S. Komariah, } \\
\text { N.F. Utami, E. Prakarsa }\end{array}$ \\
\hline 15 & $15: 50-16: 00$ & ISOT043 & $\begin{array}{l}\text { How risky is liveaboard diving in } \\
\text { Indonesia? An empirical investigation } \\
\text { on the divers perceived risk and } \\
\text { oceanic geomorphology }\end{array}$ & $\begin{array}{l}\text { R.M. Wirakusuma, M. Lück } \\
\text {, H. Schänzel, M.A. } \\
\text { Widiawaty, G.P. } \\
\text { Pramulatsih, M. Dede, E. } \\
\text { Dasipah }\end{array}$ \\
\hline 16 & $16: 10-16: 20$ & ISOT044 & $\begin{array}{l}\text { Challenges in sustainable design } \\
\text { practices through the lenses of local } \\
\text { event organizers }\end{array}$ & M. Intason \\
\hline 17 & $16: 20-16: 30$ & ISOT045 & Rural Tourism: The State-of-the-Art & A.H.G. Kusumah \\
\hline 18 & $16: 30-16: 40$ & ISOT046 & $\begin{array}{l}\text { Hand sign method in playing angklung } \\
\text { as tourists' involvement on creative }\end{array}$ & N. Riana, K. Fajri \\
\hline
\end{tabular}




\begin{tabular}{|l|l|l|l|l|}
\hline & & & $\begin{array}{l}\text { tourism: A case study on Saung } \\
\text { Angklung Udjo }\end{array}$ & \\
\hline 19 & $16: 40-16: 50$ & ISOT065 & $\begin{array}{l}\text { Implications of Food Delivery Services } \\
\text { for Recognition of Traditional Foods by } \\
\text { Millennials in Bandung }\end{array}$ & A. Sudono \\
\hline
\end{tabular}

\section{Breakout room 2: Destination Management}

\begin{tabular}{|c|c|c|c|c|}
\hline No & Time & Code & Title & Author(s) \\
\hline 1 & $13: 00-13: 10$ & ISOT015 & $\begin{array}{l}\text { The crucial attributes for culinary } \\
\text { tourism destination based on tourists' } \\
\text { perception }\end{array}$ & $\begin{array}{l}\text { T. Abdullah, Gitasiswhara, } \\
\text { R.S. Nugraha }\end{array}$ \\
\hline 2 & $13: 10-13: 20$ & ISOT016 & $\begin{array}{l}\text { Border tourism in Indonesia's outer } \\
\text { islands: The case of Sebatik Island }\end{array}$ & $\begin{array}{l}\text { S.R.P. Wulung, A.K. } \\
\text { Yuliawati, M.S.D. Hadian }\end{array}$ \\
\hline 3 & $13: 20-13: 30$ & ISOT017 & $\begin{array}{l}\text { Visitor satisfaction: The mediating role } \\
\text { of crowding perception on } \\
\text { environmental characteristic and other } \\
\text { visitors' behavior }\end{array}$ & $\begin{array}{l}\text { N.A. Zidany, G.R. } \\
\text { Nurazizah, F. Rahmafitria, } \\
\text { M.H.Y. Johari }\end{array}$ \\
\hline 4 & $13: 30-13: 40$ & ISOT018 & $\begin{array}{l}\text { Culinary Tourism Planning and } \\
\text { Development: A Case in Gebang Mekar } \\
\text { Cirebon }\end{array}$ & $\begin{array}{l}\text { E. Fitriyani, I.I. Pratiwi, A. } \\
\text { Suwandi }\end{array}$ \\
\hline 5 & $13: 40-13: 50$ & ISOT019 & $\begin{array}{l}\text { Tour Guides' Multilingualism in the City } \\
\text { of Bandung, Indonesia: What Does the } \\
\text { Policy Say? }\end{array}$ & $\begin{array}{l}\text { C.U. Abdullah, S.R.P. } \\
\text { Wulung }\end{array}$ \\
\hline 6 & $13: 50-14: 00$ & ISOT020 & $\begin{array}{l}\text { Tourist preferences of activities in the } \\
\text { tourist village }\end{array}$ & S. Marhanah, E. Sukriah \\
\hline 7 & $14: 00-14: 10$ & ISOT021 & $\begin{array}{l}\text { The influence of Bandung City image as } \\
\text { a fashion city on tourist satisfaction }\end{array}$ & $\begin{array}{l}\text { P. Supriatin, S. Marhanah, } \\
\text { Rosita }\end{array}$ \\
\hline 8 & $14: 10-14: 20$ & ISOT022 & $\begin{array}{l}\text { The influence of destination image on } \\
\text { revisit intention in Olele Marine Park }\end{array}$ & $\begin{array}{l}\text { M.N. Della, N. Wildan, O. } \\
\text { Sukirman }\end{array}$ \\
\hline 9 & $14: 20-14: 30$ & ISOT023 & $\begin{array}{l}\text { Topeng Pedalangan as a tourist } \\
\text { attraction in Gunungkidul Regency } \\
\text { Special Region of Yogyakarta }\end{array}$ & Kuswarsantyo \\
\hline 10 & $14: 30-14: 40$ & ISOT024 & $\begin{array}{l}\text { Millennial volunteer tourist motivation } \\
\text { in West Java Province, Indonesia }\end{array}$ & $\begin{array}{l}\text { D.D. Utami, I. Ramadhani, } \\
\text { A.P. Ramdhani, N.T. } \\
\text { Murtiani }\end{array}$ \\
\hline 11 & $14: 40-14: 50$ & ISOT025 & $\begin{array}{l}\text { Sacred tombs as attraction of tourism } \\
\text { village }\end{array}$ & $\begin{array}{l}\text { R. Fedrina, Khrisnamurti, } \\
\text { R. Darmawan, U. Suhud }\end{array}$ \\
\hline 12 & $14: 50-15: 00$ & ISOT026 & $\begin{array}{l}\text { Chinese tourists' perception on Bali } \\
\text { Tour Package }\end{array}$ & $\begin{array}{l}\text { H. Utami, R. Darmawan, R. } \\
\text { Wardhani, U. Suhud }\end{array}$ \\
\hline & $15: 00-15: 30$ & \multicolumn{3}{|c|}{ BREAK } \\
\hline 13 & $15: 30-15: 40$ & ISOT027 & $\begin{array}{l}\text { Transformational Leadership, } \\
\text { Perceived Organizational Support, and } \\
\text { Workplace Spirituality on Employee } \\
\text { Engagement of Restaurant Employees } \\
\text { in Surabaya }\end{array}$ & $\begin{array}{l}\text { D.C. Widjaja, R.S.T. Putri, } \\
\text { D.E. Febrianto }\end{array}$ \\
\hline 14 & $15: 40-15: 50$ & ISOT028 & $\begin{array}{l}\text { Destination personality of Labuan Bajo, } \\
\text { Indonesia: Local and foreign tourists' } \\
\text { perspectives }\end{array}$ & C.G. Chandra, S. Thio \\
\hline 15 & $15: 50-16: 00$ & ISOT029 & $\begin{array}{l}\text { Development of tourist visitor } \\
\text { management system in Tajur } \\
\text { Kahuripan Traditional Tourism Village }\end{array}$ & A. Agoes, I.N. Agustiani \\
\hline 16 & $16: 10-16: 20$ & ISOT030 & $\begin{array}{l}\text { Projected destination image on } \\
\text { Instagram amidst a pandemic: A visual } \\
\text { content analysis of Indonesian National } \\
\text { DMO }\end{array}$ & $\begin{array}{l}\text { W.N. Wan Noordin, V. } \\
\text { Sukmayadi, R.M. } \\
\text { Wirakusuma }\end{array}$ \\
\hline
\end{tabular}




\begin{tabular}{|c|c|c|l|l|}
\hline 17 & $16: 20-16: 30$ & ISOT031 & $\begin{array}{l}\text { Analysing the factors affecting the } \\
\text { purchasing decision over Malaysian } \\
\text { Batik Products }\end{array}$ & U.H. Simin, N.H.A. Rahman \\
\hline 18 & $16: 30-16: 40$ & ISOT032 & $\begin{array}{l}\text { Indonesia Mythology as Touristic } \\
\text { Attractiveness: The Story of the Queen } \\
\text { of the Southern Sea of Java Island }\end{array}$ & $\begin{array}{l}\text { M.V. Frolova, M.W. } \\
\text { Rizkyanfi, N.S. Wulan }\end{array}$ \\
\hline 19 & $16: 40-16: 50$ & ISOT033 & $\begin{array}{l}\text { The role of psychographic factors in } \\
\text { predicting volunteer tourists' stage of } \\
\text { readiness: A case of Australia }\end{array}$ & $\begin{array}{l}\text { U. Suhud, A.W. Handaru, } \\
\text { M. Allan, B. Wiratama }\end{array}$ \\
\hline
\end{tabular}

\section{Breakout room 3: Hospitality Management \& Destination Management}

\begin{tabular}{|c|c|c|c|c|}
\hline No & Time & Code & Title & Author (s) \\
\hline 1 & 13:00 - 13:10 & ISOT072 & $\begin{array}{l}\text { Re-examining sensory experience on } \\
\text { highland nature-based resort rooms }\end{array}$ & $\begin{array}{l}\text { N.H.A. Rahman, R.M. } \\
\text { Wirakusuma, E. Dasipah }\end{array}$ \\
\hline 2 & $13: 10-13: 20$ & ISOT073 & $\begin{array}{l}\text { Consumer's complaint behavior } \\
\text { between Indonesian and Non- } \\
\text { Indonesian in the hotel }\end{array}$ & $\begin{array}{l}\text { Y. Machiko, Ivena, M. } \\
\text { Kristanti, R. Jokom }\end{array}$ \\
\hline 3 & $13: 20-13: 30$ & ISOT074 & $\begin{array}{l}\text { Exploring factors influencing homestay } \\
\text { operators to participate in the } \\
\text { homestay program }\end{array}$ & $\begin{array}{l}\text { S. Haminuddin, S.S. Md } \\
\text { Sawari, S.A. Abas }\end{array}$ \\
\hline 4 & $13: 30-13: 40$ & ISOT075 & $\begin{array}{l}\text { Analysing the tourist's e-satisfaction of } \\
\text { hotel booking website towards online } \\
\text { purchase intention in Malaysia }\end{array}$ & M.M. Jamil, N.H.A. Rahman \\
\hline 5 & $13: 40-13: 50$ & ISOT076 & $\begin{array}{l}\text { Sharia-compliant hotel literacy: } \\
\text { Profiling the potential sharia-compliant } \\
\text { hotel guest }\end{array}$ & $\begin{array}{l}\text { Y. Rahayu, J. } \\
\text { Zuhriatusobah }\end{array}$ \\
\hline 6 & $13: 50-14: 00$ & ISOT077 & $\begin{array}{l}\text { Environment, food, or employee: } \\
\text { Identifying factors in authentic dining } \\
\text { experience influencing customer } \\
\text { satisfaction }\end{array}$ & $\begin{array}{l}\text { T. Abdullah, N. Latifah, } \\
\text { H.P.D. Setiyorini, R.S. } \\
\text { Nugraha }\end{array}$ \\
\hline 7 & 14:00 - 14:10 & ISOT079 & $\begin{array}{l}\text { The impact of dining experience } \\
\text { towards revisit intention at Mujigae } \\
\text { Resto, Bandung }\end{array}$ & $\begin{array}{l}\text { R. Andari, Gitasiswhara, } \\
\text { D.A.T. Putri }\end{array}$ \\
\hline 8 & $14: 10-14: 20$ & ISOT080 & $\begin{array}{l}\text { Legal and business sustainability of } \\
\text { social enterprises restaurants }\end{array}$ & $\begin{array}{l}\text { N.B. Le, T. Andrianto, R. } \\
\text { Kwong }\end{array}$ \\
\hline 9 & $14: 20-14: 30$ & ISOT081 & $\begin{array}{l}\text { Restaurant selection of Thai Free } \\
\text { Individual Traveler (FIT) by using } \\
\text { Conjoint Analysis Approach }\end{array}$ & $\begin{array}{l}\text { K. Pitchayadejanant, L. } \\
\text { Dembinski, P. Seesavat, P. } \\
\text { Yimsiri, A. Amonpon, R. } \\
\text { Suprina }\end{array}$ \\
\hline 10 & $14: 30-14: 40$ & ISOT034 & $\begin{array}{l}\text { Turkish destination image and attitude } \\
\text { toward Turkish television drama }\end{array}$ & $\begin{array}{l}\text { U. Suhud, A.W. Handaru, } \\
\text { M. Allan, B. Wiratama }\end{array}$ \\
\hline 11 & $14: 40-14: 50$ & ISOT035 & $\begin{array}{l}\text { Why do countries allow dark tourism? } \\
\text { A review study }\end{array}$ & S. Barua, E.D. Putra \\
\hline 12 & $14: 50-15: 00$ & ISOT036 & $\begin{array}{l}\text { Understanding the motivations and } \\
\text { preference on ecotourism } \\
\text { development: The case of Gunung } \\
\text { Leuser National Park, Indonesia }\end{array}$ & $\begin{array}{l}\text { Amrullah, A. Rachmatullah } \\
\text { Nurbaeti, F. Asmaniati, S. } \\
\text { P. Djati }\end{array}$ \\
\hline & $15: 00-15: 30$ & \multicolumn{3}{|c|}{ BREAK } \\
\hline 13 & $15: 30-15: 40$ & ISOT037 & $\begin{array}{l}\text { Sequential exploratory mixed methods } \\
\text { and scale development: Investigating } \\
\text { transformational tourism readiness }\end{array}$ & $\begin{array}{l}\text { J.K. Sabharwal, S. Goh, K. } \\
\text { Thirumaran }\end{array}$ \\
\hline 14 & $15: 40-15: 50$ & ISOT038 & $\begin{array}{l}\text { Economic Benefits of Selected Resorts } \\
\text { in Dasmariñas City, Cavite: Basis For A } \\
\text { Proposed Economic Strategy }\end{array}$ & $\begin{array}{l}\text { A.R.D. Movido, M.J.L. } \\
\text { Tapawan, Q.A.E. Lucero, } \\
\text { J.U. Tabuyo }\end{array}$ \\
\hline
\end{tabular}




\begin{tabular}{|c|c|l|l|l|}
\hline 15 & $15: 50-16: 00$ & ISOT039 & $\begin{array}{l}\text { Tourism development and the well- } \\
\text { being of local people: Findings from } \\
\text { Lembang, West Java, Indonesia }\end{array}$ & E. Sukriah \\
\hline 16 & $16: 10-16: 20$ & ISOT042 & $\begin{array}{l}\text { Can marine debris pollution cause the } \\
\text { loss of tourism revenue in Indonesia? } \\
\text { An empirical study }\end{array}$ & $\begin{array}{l}\text { P. Hindayani, A. Khosihan, } \\
\text { A.R. Pratama }\end{array}$ \\
\hline 17 & $16: 20-16: 30$ & ISOT047 & $\begin{array}{l}\text { Potential of domestic tourist loyalty in } \\
\text { Indonesia: A spatial analysis }\end{array}$ & $\begin{array}{l}\text { A.R. Pratama, A. Khosihan, } \\
\text { P. Hindayani }\end{array}$ \\
\hline 18 & $16: 30-16: 40$ & ISOT040 & $\begin{array}{l}\text { The effect of individual and destination } \\
\text { accessibility on willingness to visit: } \\
\text { nature-based tourism destination }\end{array}$ & $\begin{array}{l}\text { I. Wirajaya, F. Rahmafitria, } \\
\text { G.R. Nurazizah, A. Jamin }\end{array}$ \\
\hline 19 & $16: 40-16: 50$ & ISOT041 & $\begin{array}{l}\text { Push and pull factors in visiting a } \\
\text { remote nature-based destination }\end{array}$ & $\begin{array}{l}\text { R. Ameliana, L. Somantri, F. } \\
\text { Rahmafitria, F.A. Karim }\end{array}$ \\
\hline
\end{tabular}

\section{Breakout room 4: Tourism and Education \& Gastronomy Tourism}

\begin{tabular}{|c|c|c|c|c|}
\hline No & Time & Code & Title & Author (s) \\
\hline 1 & 13:00 - 13:10 & ISOT048 & The tourism academic traveler & $\begin{array}{l}\text { A.H.G. Kusumah, } \\
\text { Khrisnamurti, M. Kristanti }\end{array}$ \\
\hline 2 & $13: 10-13: 20$ & ISOT049 & $\begin{array}{l}\text { Competency development problems in } \\
\text { tourism and hospitality students' } \\
\text { internship in Indonesia }\end{array}$ & Rosita \\
\hline 3 & $13: 20-13: 30$ & ISOT050 & $\begin{array}{l}\text { Integrative Teaching Materials for } \\
\text { Indonesian Speakers of Other } \\
\text { Languages Based on Sundanese } \\
\text { Gastronomy Text }\end{array}$ & $\begin{array}{l}\text { M.W. Rizkyanfi, } \\
\text { Syihabuddin, F.N. } \\
\text { Utorodewo, V.S. } \\
\text { Damaianti, D. Turgarini }\end{array}$ \\
\hline 4 & $13: 30-13: 40$ & ISOT051 & $\begin{array}{l}\text { CIPP Model: Curriculum evaluation of } \\
\text { the Indonesian gastronomy courses }\end{array}$ & $\begin{array}{l}\text { W. Priantini, I. Abdulhak, } \\
\text { D. Wahyudin, A.H.G. } \\
\text { Kusumah }\end{array}$ \\
\hline 5 & $13: 40-13: 50$ & ISOT052 & $\begin{array}{l}\text { Situation analysis of tourism education } \\
\text { in The City of Bandung }\end{array}$ & $\begin{array}{l}\text { A. Suwandi, E. Fitriyani, N. } \\
\text { Fajria, S.R.P. Wulung }\end{array}$ \\
\hline 6 & $13: 50-14: 00$ & ISOT053 & $\begin{array}{l}\text { Analysis of online learning in pandemic } \\
\text { Covid-19 in tourism education }\end{array}$ & $\begin{array}{l}\text { A. Suwandi, E. Fitriyani, A. } \\
\text { Gumelar }\end{array}$ \\
\hline 7 & 14:00 - 14:10 & ISOT054 & $\begin{array}{l}\text { Development of friendly character and } \\
\text { working characters for Tourism Guide } \\
\text { Practices of SMK's Student in Bali }\end{array}$ & R. Munawar, M. Rahmat \\
\hline 8 & $14: 10-14: 20$ & ISOT055 & $\begin{array}{l}\text { Edutourism: Learning to be the } \\
\text { Indonesian Society }\end{array}$ & $\begin{array}{l}\text { R.W.A. Rozak, A. Kosasih, } \\
\text { M.D. Kembara, N. } \\
\text { Budiyanti, V.A. Hadian }\end{array}$ \\
\hline 9 & $14: 20-14: 30$ & ISOT056 & $\begin{array}{l}\text { Intercultural language learning: } \\
\text { Literacy level determines the } \\
\text { development of tourist numbers in } \\
\text { Indonesia? }\end{array}$ & $\begin{array}{l}\text { D. Hadianto, V.S. } \\
\text { Damaianti, Y. Mulyati, A. } \\
\text { Sastromiharjo }\end{array}$ \\
\hline 10 & $14: 30-14: 40$ & ISOT057 & $\begin{array}{l}\text { CATC implementation to strengthen the } \\
\text { industrial based tourism competency of } \\
\text { vocational school }\end{array}$ & D. Sunarja, O.D. Maharani \\
\hline 11 & $14: 40-14: 50$ & ISOT058 & $\begin{array}{l}\text { An Exploratory Study on Singapore } \\
\text { Polytechnic Hospitality and Tourism } \\
\text { Students' Perception towards the use of } \\
\text { Virtual Learning Environments (E- } \\
\text { Learning) }\end{array}$ & J.M. Pang \\
\hline 12 & $14: 50-15: 00$ & ISOT059 & $\begin{array}{l}\text { The challenge in disruptive times in } \\
\text { tourism education: Towards are } \\
\text { designed curriculum for new normal } \\
\text { from conventional to creative tourism }\end{array}$ & P.R.M. Tayko, Foedjiawati \\
\hline & $15: 00-15: 30$ & \multicolumn{3}{|c|}{ BREAK } \\
\hline
\end{tabular}




\begin{tabular}{|c|c|c|c|c|}
\hline 13 & $15: 30-15: 40$ & ISOT060 & $\begin{array}{l}\text { The suitability of TOEFL-ITP as a } \\
\text { tourism industry employment } \\
\text { requirement for Indonesian university } \\
\text { graduates }\end{array}$ & G. Ginanjar, M.W. Rizkyanfi \\
\hline 14 & $15: 40-15: 50$ & ISOT067 & $\begin{array}{l}\text { Digitalization activities in gastronomy } \\
\text { tourism }\end{array}$ & $\begin{array}{l}\text { D. Turgarini, I.I. Pratiwi, } \\
\text { T.K. Priyambodo }\end{array}$ \\
\hline 15 & $15: 50-16: 00$ & ISOT068 & $\begin{array}{l}\text { Tape Kareueut Teh Bohay: Students' } \\
\text { Gastronomic Tourism Capital } \\
\text { Universitas Pendidikan Indonesia }\end{array}$ & $\begin{array}{l}\text { Fachrudin, N.N. Afidah, F. } \\
\text { Azis, S. Hamidah, M.W. } \\
\text { Rizkyanfi }\end{array}$ \\
\hline 16 & $16: 10-16: 20$ & ISOT070 & $\begin{array}{l}\text { Exploring the expectation of youth } \\
\text { purchasing intention for street food as } \\
\text { a gastronomy tourism in Bangsaen, } \\
\text { Thailand }\end{array}$ & $\begin{array}{l}\text { P. Nakpathom, K. } \\
\text { Chinnapha, P. Lakanavisid, } \\
\text { M.R. Putra, A. Wongla, A. } \\
\text { Kowarattanakul, N. } \\
\text { Pangket, P. Thanuthep, } \\
\text { S.H. Rui }\end{array}$ \\
\hline 17 & $16: 20-16: 30$ & ISOT071 & $\begin{array}{l}\text { iDabao during Covid-19: Online-to- } \\
\text { offline (020) food delivery service and } \\
\text { the digitalization of hawker (street) } \\
\text { food during a crisis }\end{array}$ & E. Tan \\
\hline 18 & $16: 30-16: 40$ & ISOT069 & $\begin{array}{l}\text { Gastronomy Tourism Development } \\
\text { Model on a Tourist Village }\end{array}$ & $\begin{array}{l}\text { C. Ningsih, D. Turgarini, I.I. } \\
\text { Pratiwi, R. Fitrianty }\end{array}$ \\
\hline 19 & $16: 40-16: 50$ & ISOT088 & $\begin{array}{l}\text { Assessing Tourist Motivation on } \\
\text { Tionghoa Halal Food }\end{array}$ & C. Ningsih, H. Taufiq A \\
\hline
\end{tabular}

\section{Breakout room 5: Security and Crisis Management in Tourism}

\begin{tabular}{|c|c|c|c|c|}
\hline No & Time & Code & Title & Author (s) \\
\hline 1 & $13: 00-13: 10$ & ISOT082 & $\begin{array}{l}\text { Covid-19 and Indonesian super-priority } \\
\text { tourism destinations }\end{array}$ & $\begin{array}{l}\text { S.R.P. Wulung, Y. } \\
\text { Yuniawati, R. Andari }\end{array}$ \\
\hline 2 & $13: 10-13: 20$ & ISOT083 & $\begin{array}{l}\text { The influence of perceived risk and } \\
\text { perceived value toward tourist } \\
\text { satisfaction }\end{array}$ & $\begin{array}{l}\text { B. Waluya, O. Ridwanudin, } \\
\text { Z.S. Zahirah }\end{array}$ \\
\hline 3 & $13: 20-13: 30$ & ISOT084 & $\begin{array}{l}\text { Hospitality Industry Crisis: How to } \\
\text { Survive and Recovery in The Pandemic } \\
\text { of COVID-19 }\end{array}$ & $\begin{array}{l}\text { E. Fitriyani, D.P. Novalita, } \\
\text { Labibatussolihah }\end{array}$ \\
\hline 4 & $13: 30-13: 40$ & ISOT085 & $\begin{array}{l}\text { From fantasy to reality: Attracting the } \\
\text { premium tourists after COVID-19 }\end{array}$ & $\begin{array}{l}\text { A.R. Pratama, P. Hindayani, } \\
\text { A. Khosihan }\end{array}$ \\
\hline 5 & $13: 40-13: 50$ & ISOT086 & $\begin{array}{l}\text { Travel decision-making amid the } \\
\text { pandemic }\end{array}$ & G.R. Nurazizah, Darsiharjo \\
\hline 6 & $13: 50-14: 00$ & ISOT089 & $\begin{array}{l}\text { Revenge Tourism : Trend or Impact } \\
\text { Post Pandemic Covid-19? }\end{array}$ & M.N.A. Abdullah \\
\hline 7 & $14: 00-14: 10$ & ISOT090 & $\begin{array}{l}\text { Spiritual tourism: Study of the } \\
\text { experience of fasting on Ramadan } \\
\text { during the COVID-19 pandemic in } \\
\text { Indonesia }\end{array}$ & E. Firdaus, M. Rahmat \\
\hline 8 & $14: 10-14: 20$ & ISOT091 & $\begin{array}{l}\text { The new era of tourism: Draw up } \\
\text { tourism industry after pandemic }\end{array}$ & $\begin{array}{l}\text { S. Nurbayani, F.N. } \\
\text { Asyahidda }\end{array}$ \\
\hline 9 & $14: 20-14: 30$ & ISOT092 & $\begin{array}{l}\text { Tourism and tourism crisis } \\
\text { management in the COVID-19 } \\
\text { pandemic time }\end{array}$ & E. Edison, T. Kartika \\
\hline 10 & $14: 30-14: 40$ & ISOT093 & $\begin{array}{l}\text { Differences in trust and risk-taking } \\
\text { propensity for travelers from Indonesia }\end{array}$ & A. Njo, F. Andreani \\
\hline 11 & $14: 40-14: 50$ & ISOT094 & $\begin{array}{l}\text { The impact of travel constraints on } \\
\text { travel intention }\end{array}$ & F. Andreani, A. Njo \\
\hline 12 & $14: 50-15: 00$ & ISOT095 & $\begin{array}{l}\text { The effect of COVID-19 outbreak to the } \\
\text { destination choice and the intention to }\end{array}$ & $\begin{array}{l}\text { M. Worrachananun, N. } \\
\text { Srisuksai }\end{array}$ \\
\hline
\end{tabular}




\begin{tabular}{|c|c|c|c|c|}
\hline & & & $\begin{array}{l}\text { visit the destination among Thai } \\
\text { tourists }\end{array}$ & \\
\hline & $15: 00-15: 30$ & \multicolumn{3}{|c|}{ BREAK } \\
\hline 13 & $15: 30-15: 40$ & ISOT096 & $\begin{array}{l}\text { The impacts of COVID-19 at } \\
\text { Karangsong Mangrove Centre }\end{array}$ & $\begin{array}{l}\text { D.J. Prihadi, Z. Guanghai, } \\
\text { Khrisnamurti, H. Nuraeni }\end{array}$ \\
\hline 14 & $15: 40-15: 50$ & ISOT097 & $\begin{array}{l}\text { Impacts of COVID-19 on national } \\
\text { security in Indonesia and the } \\
\text { alternative of national policy solutions }\end{array}$ & $\begin{array}{l}\text { A.M. Fawzi, A.T. Nugraha, } \\
\text { A.G. Subakti }\end{array}$ \\
\hline 15 & $15: 50-16: 00$ & ISOT098 & $\begin{array}{l}\text { Covid-19, Technology and Tourism: the } \\
\text { future of virtual tour? }\end{array}$ & $\begin{array}{l}\text { T. Andrianto, A.H.G. } \\
\text { Kusumah, N.A. Md Rashid, } \\
\text { A.G. Buja, M.A. Arshad }\end{array}$ \\
\hline 16 & $16: 10-16: 20$ & ISOT099 & $\begin{array}{l}\text { Virtual tour as one of education tourism } \\
\text { solutions in COVID-19 pandemic }\end{array}$ & R. Khaerani \\
\hline 17 & $16: 20-16: 30$ & ISOT100 & $\begin{array}{l}\text { Estimation of short-term economic } \\
\text { effect in Geopark Ciletuh- } \\
\text { Palabuhanratu tourism due to the } \\
\text { coronavirus outbreak }\end{array}$ & $\begin{array}{l}\text { P. Hindayani, A.R. Pratama, } \\
\text { A. Khosihan, Z. Anna }\end{array}$ \\
\hline 18 & $16: 30-16: 40$ & ISOT087 & $\begin{array}{l}\text { Tourism Industry Standard Operating } \\
\text { Procedure Adaptation Preparing Covid- } \\
19 \text { New Normal in Indonesia }\end{array}$ & $\begin{array}{l}\text { I.I. Pratiwi, A. } \\
\text { Mahmudatussa'adah }\end{array}$ \\
\hline
\end{tabular}

\begin{tabular}{|c|c|c|c|c|}
\hline No & Time & Code & Title & Author (s) \\
\hline 1 & $13: 00-13: 10$ & ISOT101 & $\begin{array}{l}\text { The effect of tourist satisfaction in the } \\
\text { relationship between experiential } \\
\text { marketing and revisit intention in } \\
\text { Dusun Bambu, Indonesia }\end{array}$ & $\begin{array}{l}\text { R. Khaerani, T. Kartika, B. } \\
\text { Basri }\end{array}$ \\
\hline 2 & $13: 10-13: 20$ & ISOT102 & $\begin{array}{l}\text { Virtual public sphere: The overview of } \\
\text { instagram users in responding to the } \\
\text { instagram posts of tourist destination } \\
\text { in COVID- } 19 \text { pandemic }\end{array}$ & $\begin{array}{l}\text { A. Khosihan, P. Hindayani, } \\
\text { A.R. Pratama }\end{array}$ \\
\hline 3 & $13: 20-13: 30$ & ISOT103 & $\begin{array}{l}\text { Visual Ethnography: Tourists' } \\
\text { Perception of Bandung's Destination } \\
\text { Image }\end{array}$ & $\begin{array}{l}\text { O. Ridwanudin, Y. } \\
\text { Yuniawati, V. Gaffar }\end{array}$ \\
\hline 4 & $13: 30-13: 40$ & ISOT104 & $\begin{array}{l}\text { What makes visitors come again to } \\
\text { food festivals? An analysis of a direct } \\
\text { influence of culinary festival attributes }\end{array}$ & $\begin{array}{l}\text { T. Abdullah, N.E. Novianti, } \\
\text { R. Andari, R.S. Nugraha }\end{array}$ \\
\hline 5 & $13: 40-13: 50$ & ISOT105 & $\begin{array}{l}\text { Women's mountaineering tourism on } \\
\text { Instagram: the paradox between } \\
\text { gender equality, identity, and } \\
\text { objectification }\end{array}$ & A. Mecca \\
\hline 6 & $13: 50-14: 00$ & ISOT106 & $\begin{array}{l}\text { Image of } 10 \text { prioritized tourism } \\
\text { destinations and its influence on eWOM } \\
\text { among tourism students }\end{array}$ & $\begin{array}{l}\text { T. A. Patria, H. Ulinnuha, Y. } \\
\text { Maulana, J. Denver, J. } \\
\text { Tanika }\end{array}$ \\
\hline 7 & $14: 00-14: 10$ & ISOT107 & $\begin{array}{l}\text { Nation brand culture tourism to } \\
\text { improve the Nation image }\end{array}$ & $\begin{array}{l}\text { Wilodati, S. Komariah, N.F. } \\
\text { Utami }\end{array}$ \\
\hline 8 & $14: 10-14: 20$ & ISOT108 & $\begin{array}{l}\text { The role of social media in Generation } \mathrm{Z} \\
\text { travel decision-making process }\end{array}$ & $\begin{array}{l}\text { Khrisnamurti, R. Fedrina, } \\
\text { U. Suhud, D.J. Prihadi }\end{array}$ \\
\hline 9 & $14: 20-14: 30$ & ISOT109 & $\begin{array}{l}\text { The influence of halal tourism } \\
\text { destination attributes on tourist } \\
\text { satisfaction in Bandung }\end{array}$ & $\begin{array}{l}\text { N. Wildan, M.N. Della, O. } \\
\text { Sukirman }\end{array}$ \\
\hline 10 & $14: 30-14: 40$ & ISOT110 & $\begin{array}{l}\text { mGuiding (Mobile Guiding) - Using a } \\
\text { Mobile GIS app for Guiding Geopark } \\
\text { Ciletuh Palabuhanratu, Indonesia }\end{array}$ & $\begin{array}{l}\text { R. Arrasyid, Darsiharjo, M. } \\
\text { Ruhimat, D.S. Logayah, R. } \\
\text { Ridwana, H.R.M. Isya }\end{array}$ \\
\hline
\end{tabular}




\begin{tabular}{|c|c|c|c|c|}
\hline 11 & $14: 40-14: 50$ & ISOT111 & $\begin{array}{l}\text { Virtual tour: Tourism opportunities in } \\
\text { the new normal era }\end{array}$ & $\begin{array}{l}\text { Labibatussolihah, D.P. } \\
\text { Novalita, N. Fathiraini, E. } \\
\text { Fitriyani }\end{array}$ \\
\hline 12 & $14: 50-15: 00$ & ISOT112 & $\begin{array}{l}\text { The Effect of Internet Marketing and } \\
\text { Electronic Word of Mouth of Sundanese } \\
\text { Gastronomy Tourism on Tourist Visit } \\
\text { Motivation to Bandung }\end{array}$ & $\begin{array}{l}\text { D. Valentina, D. Turgarini, } \\
\text { I.I. Pratiwi }\end{array}$ \\
\hline & $15: 00-15: 30$ & & Break & \\
\hline 13 & $15: 30-15: 40$ & ISOT061 & $\begin{array}{l}\text { Canna fettucine: Commodifying } \\
\text { culinary Italian Indonesian }\end{array}$ & $\begin{array}{l}\text { S.S. Wachyuni, K. Wiweka, } \\
\text { R.M. Wirakusuma }\end{array}$ \\
\hline 14 & $15: 40-15: 50$ & ISOT062 & $\begin{array}{l}\text { The Salapan Cinyusu (Nona Helix) as a } \\
\text { "creativepreneurship" support model } \\
\text { for gastronomy tourism in Bandung } \\
\text { city }\end{array}$ & D. Turgarini \\
\hline 15 & $15: 50-16: 00$ & ISOT063 & $\begin{array}{l}\text { The effect of gastronomic festival } \\
\text { attributes on behavioral intention at } \\
\text { Wisata Kuliner Tjeplak Purwakarta }\end{array}$ & $\begin{array}{l}\text { Rr.M. Vania T., } \\
\text { Gitasiswhara, Y. Yuniawati }\end{array}$ \\
\hline 16 & $16: 10-16: 20$ & ISOT064 & $\begin{array}{l}\text { Culinary experience toward behavioral } \\
\text { intention (Survey of consumer fusion } \\
\text { food on street food in Bandung City) }\end{array}$ & $\begin{array}{l}\text { M.R. Perdana, L.A. } \\
\text { Wibowo, Gitasiswhara }\end{array}$ \\
\hline 17 & $16: 20-16: 30$ & ISOT066 & $\begin{array}{l}\text { Gastronomy tourism as a media to } \\
\text { strengthen national identity }\end{array}$ & $\begin{array}{l}\text { R. Fitria, A. Supriatna, K.A. } \\
\text { Hakam, S. Nurbayani, } \\
\text { Warlim }\end{array}$ \\
\hline 18 & $16: 30-16: 40$ & ISOT078 & $\begin{array}{l}\text { The effect of perceived authenticity on } \\
\text { revisit intention in Sundanese } \\
\text { Restaurant }\end{array}$ & $\begin{array}{l}\text { Y. Yuniawati, T. Abdullah, } \\
\text { A.S. Sonjaya }\end{array}$ \\
\hline
\end{tabular}




\title{
HOSPITALITY MANAGEMENT
}

ISOT072

\section{Re-examining sensory experience on highland nature-based resort rooms}

\author{
N.H.A. Rahman \\ International Islamic University Malaysia, Johor, Malaysia \\ R.M. Wirakusuma \\ Universitas Pendidikan Indonesia, Bandung, Indonesia \\ E. Dasipah \\ Universitas Winaya Mukti, Bandung, Indonesia
}

\begin{abstract}
Tourists are more likely to seek hotel and resort reviews before making a reservation. However, the advertised products are sometimes not in accordance with their actual staying experience. Experience is conceptualized as a combination of senses, influence, and cognition. This research aims to find out the sensory experience by the Resort's guests based on the online reviews as the secondary data. The reviews were gathered from online travel agents, namely Traveloka, Agoda, and TripAdvisor.com. The collected data were analyzed sentence by sentence to discover the sensory experience that has been felt by the guests while staying in the resorts. It can be concluded that the sight experience was related to the superiority of a good view from nature, the serenity as the primary factor for the hearing experience but some rooms in the resorts were not soundproof, and eventually, it had influenced the unpleasant experience to the guests. Furthermore, the un-pleasant touch and smell experience of these resorts were the nuisances from the insects, stiff mattress, and the uncomfortable bathroom. But, the breeze from nature has completed the whole relaxation experience. Hence, this research provides implication on the improvement of guest's experience in the context of five senses in the hospitality and tourism industry.
\end{abstract}

Keywords: sensory experience, senses, unique accommodation, highland nature-based resort, online travel agents 